\title{
Speciation of trace amounts of aluminium in environmental samples by cation-exchange FPLC - ETAAS
}

\author{
B. Mitrović ${ }^{1}$, R. Milačič ${ }^{1, *}$, B. Pihlar ${ }^{2}$ and P. Simončič ${ }^{3}$ \\ ${ }^{1}$ Department of Environmental Sciences, Jožef Stefan Institute, 1000 Ljubljana, Slovenia \\ ${ }^{2}$ Faculty of Chemistry and Chemical Technology, University of Ljubljana, Aškerčeva 5, 1000 Ljubljana, Slovenia \\ ${ }^{3}$ Institute for Forestry, Večna pot 2, 1000 Ljubljana, Slovenia
}

\begin{abstract}
Cation-exchange fast protein liquid chromatography - electrothermal atomic absorption spectrometry (FPLC - ETAAS) was applied for the speciation of trace amounts of aluminium. An aqueous $8 \mathrm{~mol} \mathrm{dm}^{-3} \mathrm{NH}_{4} \mathrm{NO}_{3}$ linear gradient elution in $10 \mathrm{~min}-$ utes enabled separation of positively charged monomeric aluminium species in aqueous solution. Separated aluminium species were collected in $0.5 \mathrm{~cm}^{3}$ fractions and aluminium determined "off line" after fourfold dilution by ETAAS. The ability of $\mathrm{NH}_{4} \mathrm{NO}_{3}$ to completely decompose at low temperature in the graphite tube during the ashing step enabled quantitative and reproducible determination of aluminium. After applying Chelex-100 resin in a cleaning procedure of the eluent, the eluent blank was very low $\left(<1.0 \mathrm{ng} \mathrm{cm}{ }^{-3} \mathrm{Al}\right)$. When $1 \mathrm{~cm}^{3}$ of sample was injected on the column resin, the limit of detection $(3 \mathrm{~s})$ for the separated aluminium species determined by ETAAS was found to be $3 \mathrm{ng} \mathrm{cm}^{-3}$. Good repeatability of measurement of separated aluminium species (relative standard deviation $\pm 5 \%$ ) was obtained under the recommended analytical conditions. The influence of some inorganic and organic complexing ligands at $\mathrm{pH}$ values of 4.0 and 6.0 on the speciation of aluminium was also investigated. The method developed was successfully applied for the speciation of aluminium in soil extracts and natural water samples at $\mathrm{ng} \mathrm{cm}^{-3}$ levels.
\end{abstract}

Key words. Speciation of trace amounts of aluminium - fast protein liquid chromatography-electrothermal atomic absorption spectrometry - soil extracts - natural waters.

\section{Introduction}

The toxicity of aluminium towards organisms of terrestrial $[1,2]$ and aquatic $[3,4]$ habitats depends primarily on its specific forms. Labile positively charged monomeric forms of aluminium $\left(\mathrm{Al}^{3+}, \mathrm{Al}(\mathrm{OH})^{2+}\right.$ and $\left.\mathrm{Al}(\mathrm{OH})_{2}^{+}\right)$have been recognised as the most toxic aluminium species [1-5]. Therefore, investigations were directed to the development of analytical methods which enable determination not only of the sum of positively charged monomeric aluminium species [6-17] but also allow distinction between particular aluminium forms [18-27]. In recent years ion chromatography in combination with post-column derivatization using UV-VIS $[18,19]$ or fluorescence detection [20,21] were frequently employed for speciation of cationic aluminium complexes. Fluoro-, oxalato-, and citrato- aluminium species were identified by distinct peaks and separated from sulphato- aluminium which was eluted at the retention time of $\mathrm{Al}^{3+}$ [18]. Willett [19] and Gibson et al. [20] applied ion chromatography for speciation of aluminium in soil extracts. Free aluminium $\left(\mathrm{Al}^{3+}, \mathrm{Al}(\mathrm{OH})^{2+}, \mathrm{Al}(\mathrm{OH})_{2}^{+}\right.$and $\left.\mathrm{Al}\left(\mathrm{SO}_{4}\right)^{+}\right)$was separated from doubly charged $\mathrm{AlF}^{2+}$ and singly charged aluminium species $\left(\mathrm{AlF}_{2}^{+}, \mathrm{Al}(\mathrm{ox})^{+}\right.$and $\left.\mathrm{Al}(\mathrm{Hcit})^{+}\right)$. Jones et al. [21] reported speciation of aluminium in drinking waters. Aqua- and hydroxo- monomeric aluminium species were separated from $\mathrm{AlF}^{2+}, \mathrm{AlF}_{2}{ }^{+}$and aluminium bound to organic complexes. HPLC cation-exchange chromatography with fluorescence detection [22] enabled separation of soluble complexes of aluminium with fluoride, citrate, acetate and silicate from aqua- and hydroxy- aluminium species. Ion chromatography in combination with size-exclusion and cation-exchange columns using "on line" detection via postcolumn UV photometry as well as atomic spectrometry was also applied for determination of $\mathrm{Al}^{3+}$ and fluoro-, oxalatoand citrato- aluminium complexes in the $\mathrm{pH}$ range from 3 to 5 [23]. Cation-exchange HPLC and size-exclusion HPLC methods with fluorescence detection were used for speciation of complexed aluminium (citrato-, oxalato- and fluoroaluminium species) and $\mathrm{Al}^{3+}$ in soil extracts [24]. Michalas et al. [25] applied a single technique for speciation of aluminium in soil solutions and xylem saps using ion-pair chromatography with fluorescence detection. Negatively, neutral and positively charged complexes of low molecular weight organic acids were separated from $\mathrm{AlF}^{2+}$ and from $\mathrm{Al}^{3+}$ species. In our previous investigation a cation-exchange fast protein liquid chromatography procedure with ICP-AES detection was developed [26] for speciation of monomeric aluminium species. By employing aqueous $8 \mathrm{~mol} \mathrm{dm}^{-3}$ $\mathrm{NaNO}_{3}$ linear gradient elution quantitative determination of individual monomeric aluminium species $\left(\mathrm{Al}^{3+}, \mathrm{Al}(\mathrm{OH})^{2+}\right.$ and $\left.\mathrm{Al}(\mathrm{OH})_{2}^{+}\right)$in pure aqueous solutions was obtained, which is of great importance in studies of aluminium toxicity. When other chromatographic techniques were used [18-25] these species were not separated and were eluted as a single chromatographic peak. However, in complex sample matrices positively charged $\mathrm{Al}\left(\mathrm{SO}_{4}\right)^{+}$and $\mathrm{AlF}_{2}^{+}$species as well as negatively charged oxalato- and citrato- aluminium complexes coelute with $\mathrm{Al}(\mathrm{OH})_{2}{ }^{+}$species, while $\mathrm{AlF}^{2+}$

* Correspondence and reprints.

Received May 26, 1998; revised August 26, 1998; accepted September 8, 1998. 
coelutes with $\mathrm{Al}(\mathrm{OH})^{2+}$ species. The technique was successfully employed for speciation of aluminium in soil extracts $[26,27]$ and percolating water samples [27] where concentrations of total aluminium were higher than $0.5 \mu \mathrm{g} \mathrm{cm}^{-3}$.

Most natural water samples and some soil extracts contain very low aluminium concentrations. Since there is still a lack of reliable analytical procedures for speciation of aluminium in such environmental samples, the aim of our work was to investigate possibilities for speciation of aluminium at $\mathrm{ng} \mathrm{\textrm {cm } ^ { - 3 }}$ level employing cation-exchange FPLC ETAAS. For this purpose the choice of a suitable eluent which would make possible quantitative separation of aluminium species on FPLC column and reliable determination of separated species by ETAAS is of great importance. Gradient elution with $\mathrm{NH}_{4} \mathrm{NO}_{3}$ was investigated and the method applied for the speciation of low concentrations of aluminium in soil extracts and natural waters.

\section{Experimental}

\section{Instrumentation}

A strong cation-exchange FPLC Mono S HR 5/5 column (Pharmacia, Uppsala, Sweden) (column dimensions $5 \times$ $50 \mathrm{~mm}, 10 \mu \mathrm{m}$ beaded hydrophilic polyether resin substituted with methyl sulphonate groups, $\mathrm{pH}$ stability $2-12$, recommended working column pressure up to 50 bar) was employed for the separation of aluminium species. The column was connected to a Merck-Hitachi (Darmstadt, Germany) 6200 intelligent gradient pump, equipped with a Rheodyne (Cotati, CA, USA) Model 7161 injector $\left(1 \mathrm{~cm}^{3}\right.$ loop). Separated aluminium species as well as total aluminium were determined by electrothermal atomic absorption spectrometry on a Hitachi Z-8270 polarized Zeeman atomic absorption spectrophotometer at a wavelength of $309.3 \mathrm{~nm}$.

A Heraeus (Osterode, Germany) Model 17S Sepatech Biofuge was used for centrifugation of soil extracts.

A Norell Unifet (Mays Landing, NJ, USA) Microprocessor $\mathrm{pH}$ meter with an ISFET sensor was employed to determine the $\mathrm{pH}$ of samples.

\section{Reagents}

Merck suprapur acids and water doubly distilled in quartz were used for the preparation of samples and standard solutions. All other chemicals were of analytical-reagent grade and were additionally purified to remove trace amounts of aluminium.

\section{Aluminium standards}

A standard aluminium stock solution $\left(\mathrm{Al}\left(\mathrm{NO}_{3}\right)_{3} \cdot 9 \mathrm{H}_{2} \mathrm{O}\right.$, $1000 \mu \mathrm{g} \mathrm{cm}^{-3} \mathrm{Al}$ in $\mathrm{HNO}_{3} 0.5 \mathrm{~mol} \mathrm{dm}^{-3}$ ) was obtained from Merck. Fresh working standards were prepared by dilution of the stock solution with water each day.

Al-citrate and Al-oxalate complexes were made by mixing the $\mathrm{Al}\left(\mathrm{NO}_{3}\right)_{3} \cdot 9 \mathrm{H}_{2} \mathrm{O}$ stock solution with an appropriate amount of ligand (100:1 ligand to aluminium ratio) and $\mathrm{Al}_{2}\left(\mathrm{SO}_{4}\right)_{3} \cdot 18 \mathrm{H}_{2} \mathrm{O}, \mathrm{AlCl}_{3} \cdot 6 \mathrm{H}_{2} \mathrm{O}$ and $\mathrm{AlF}_{3} \cdot 3 \mathrm{H}_{2} \mathrm{O}$ (Merck) were used in studies of the influence of inorganic ligands on the speciation of aluminium. Solid humic acid (IHSS soil humic acid standard IS102H) was used to form Al-humate complex. The concentration of humic acid in the solution $\left(150 \mu \mathrm{g} \mathrm{cm}^{-3}\right)$ was more than adequate for complexation of added $\mathrm{Al}^{3+}$ ions [28].

\section{Buffer solutions}

Merck chemicals were used. Potassium hydrogen-phthalate $\left(0.05 \mathrm{~mol} \mathrm{dm}^{-3}\right)$ buffer solution with addition of an appropriate amount of nitric acid $\left(0.5 \mathrm{~mol} \mathrm{dm}^{-3}\right)$ or potassium hydroxide $\left(0.5 \mathrm{~mol} \mathrm{dm}^{-3}\right)$ was used to adjust the $\mathrm{pH}$ in the range $3.0-6.5$. For the neutral $\mathrm{pH}$ range imidazole $\left(\mathrm{C}_{3} \mathrm{H}_{4} \mathrm{~N}_{2}\right)$

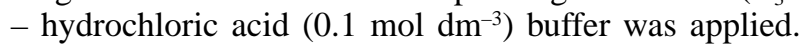

\section{Reagents in cation-exchange FPLC separations}

Merck ammonium nitrate $\left(8 \mathrm{~mol} \mathrm{dm}^{-3}\right)$ was prepared by dissolving $640.32 \mathrm{~g}$ of $\mathrm{NH}_{4} \mathrm{NO}_{3}$ in water and diluted to $1 \mathrm{dm}^{3}$. Sigma chelating ion-exchange resin Chelex-100 $\left(\mathrm{Na}^{+}\right.$form, $100-200 \mathrm{mesh}$ ) was used for cleaning of the ammonium nitrate solution.

\section{Filters}

Sartorius cellulose nitrate membrane filters of $25 \mathrm{~mm}$ diameter and 0.45 and $0.1 \mu \mathrm{m}$ pore size were used in the filtration procedure.

\section{Recommended cleaning procedure}

Sample preparation, chromatographic separations and ETAAS determinations were carried out under clean-room conditions (class 10000). Teflon flasks and polyethylene laboratory ware were used. Before application the laboratory ware was treated with $10 \% \mathrm{HNO}_{3}$ for 24 hours, rinsed well with water and dried at room temperature.

In order to lower the blank in FPLC separations, $\mathrm{NH}_{4} \mathrm{NO}_{3}$ eluent was purified before use by a batch chelating ionexchange procedure. $5 \mathrm{~g}$ of Chelex-100 $\left(\mathrm{Na}^{+}\right.$form, $100-$ 200 mesh) was added to $1 \mathrm{dm}^{3}$ of $8 \mathrm{~mol} \mathrm{dm}^{-3}$ ammonium nitrate solution and stirred for $24 \mathrm{~h}$. After that, the solution was decanted and passed through a $5 \mathrm{~cm}^{3}$ column (flow rate $0.2 \mathrm{~cm}^{3} \mathrm{~min}$ ) filled with the same resin. After applying this cleaning procedure the concentration of aluminium in the eluent was below $1 \mathrm{ng} \mathrm{cm}$.

\section{Sample preparation}

In order to study the distribution of aluminium species over a wide $\mathrm{pH}$ range, $45 \mathrm{~cm}^{3}$ of buffer solution was first adjusted to the required $\mathrm{pH}$ and transferred to a $50 \mathrm{~cm}^{3}$ calibrated flask. An appropriate amount of the stock standard solution of aluminium was added and the flask was filled to the mark with buffer. Filtered $(0.1 \mu \mathrm{m})$ synthetic standard solutions were used.

For speciation of aluminium in soil extracts, $2.00 \mathrm{~g}$ of moist soil sample were shaken for $16 \mathrm{~h}$ with $20 \mathrm{~cm}^{3}$ of water, centrifuged (10 $000 \mathrm{rpm}, 20 \mathrm{~min}$ ) and decanted. The soil extract was then filtered through a $0.45 \mu \mathrm{m}$ filter, followed by filtration through a $0.1 \mu \mathrm{m}$ filter. Aliquots of these solutions were used for the determination of $\mathrm{pH}$, total water-soluble aluminium by ETAAS and various aluminium species by cation-exchange FPLC - ETAAS. Natural water samples were filtered as for soil extracts and analysed under the same procedure. 


\section{Recommended cation-exchange FPLC - ETAAS procedure for determination of aluminium species}

$1 \mathrm{~cm}^{3}$ of sample was injected on a Mono S HR 5/5 strong cation-exchange column. An aqueous $8 \mathrm{~mol} \mathrm{dm}^{-3} \mathrm{NH}_{4} \mathrm{NO}_{3}$ $\left(0-100 \% 8 \mathrm{~mol} \mathrm{dm}{ }^{-3} \mathrm{NH}_{4} \mathrm{NO}_{3}\right)$ linear gradient elution was applied for $10 \mathrm{~min}$ at a flow rate of $1.0 \mathrm{~cm}^{3} \mathrm{~min}^{-1}$. After separation, the column was regenerated for $1 \mathrm{~min}$ with $8 \mathrm{~mol}$ $\mathrm{dm}^{-3} \mathrm{NH}_{4} \mathrm{NO}_{3}$ at a flow rate of $1.0 \mathrm{~cm}^{3} \mathrm{~min}^{-1}$ and equilibrated with water before the next separation. Equilibration was performed firstly for $3 \mathrm{~min}$ at a flow rate of $1.0 \mathrm{~cm}^{3} \mathrm{~min}^{-1}$, in the following $25 \mathrm{~min}$ at a flow rate of $2.0 \mathrm{~cm}^{3} \mathrm{~min}^{-1}$ and in the last $2 \mathrm{~min}$ at a flow rate of $1.0 \mathrm{~cm}^{3} \mathrm{~min}^{-1}$. Separated aluminium species were determined in $0.5 \mathrm{~cm}^{3}$ eluent fractions "off line" by ETAAS after four fold dilution with water prior to measurement.

\section{Results and discussion}

\section{Optimisation of the FPLC - ETAAS procedure}

In order to improve the sensitivity of the previously developed FPLC - ICP-AES method [26] for speciation of aluminium in environmental samples, a more sensitive technique should be applied for determination of separated aluminium species. For this purpose the ETAAS technique was applied. $\mathrm{NaNO}_{3}$, which was previously used as eluent [26], was not suitable for ETAAS determinations due to the residual deposit in the graphite tube. The results were not reliable enough since the sensitivity of measurements changed during successive determinations. Applying aqueous $3.5 \mathrm{~mol} \mathrm{dm}^{-3} \mathrm{Mg}\left(\mathrm{NO}_{3}\right)_{2}$ gradient elution, quantitative separation of aluminium species was obtained on the column. However, ETAAS determinations were not reliable due to similar problems arising from the salt deposit. In addition, the column pressure was considerably increased (up to 70 bar) which could shorten column lifetime. Therefore, the suitability of $\mathrm{NH}_{4} \mathrm{NO}_{3}$ eluent was investigated. Aqueous $8 \mathrm{~mol} \mathrm{dm}^{-3} \mathrm{NH}_{4} \mathrm{NO}_{3}$ linear gradient elution enabled quantitative separation of aluminium species in a wide $\mathrm{pH}$ range from 3.0 to 8.0. To obtain reproducible results efficient washing of the column with water before the next separation is necessary. During a chromatographic run the $\mathrm{pH}$ of the water- $\mathrm{NH}_{4} \mathrm{NO}_{3}$ eluent ranged from 7.0 to 6.0. The $\mathrm{pH}$ of the eluent did not influence the separation of aluminium species either in synthetic samples or in soil extracts, since the former were buffered and the latter have their own buffer capacity [26]. When natural waters (low buffer capacity) were analysed, the $\mathrm{pH}$ of the eluent was adjusted with buffer to the $\mathrm{pH}$ of sample analysed. The use of $\mathrm{NH}_{4} \mathrm{NO}_{3}$ eluent offered some important advantages. The column pressure was very low (up to 25 bar). The reagent was efficiently purified by the recommended cleaning procedure. The ability of $\mathrm{NH}_{4} \mathrm{NO}_{3}$ to decompose quantitatively in the graphite tube to $\mathrm{N}_{2} \mathrm{O}$ and $\mathrm{H}_{2} \mathrm{O}$ at $210{ }^{\circ} \mathrm{C}$ was its main advantage. Careful drying and ashing of samples in the graphite tube by slow temperature ramp as presented in table I (measurement parameters) enabled reproducible measurements of separated aluminium species. Due to the low amount of $\mathrm{NH}_{4} \mathrm{NO}_{3}$ introduced in the graphite tube, there was no possibility for a microexplosion during the heating period. Pyrolitically coated graphite tubes were used and integrated absorbances used for the calculation of aluminium concentrations. Although the concentration of $\mathrm{NH}_{4} \mathrm{NO}_{3}$ increased during the chromatographic run (gradient elution), determination of aluminium in the separated fractions was interference-free due to the efficient thermal matrix decomposition. It was found experimentally that calibration based on aqueous standards could be applied in the determinations of separated aluminium species.

\section{Influence of $\mathrm{pH}$ on the distribution of aluminium species}

A standard solution of $250 \mathrm{ng} \mathrm{cm}{ }^{-3} \mathrm{Al}\left(\mathrm{Al}\left(\mathrm{NO}_{3}\right)_{3} \cdot 9 \mathrm{H}_{2} \mathrm{O}\right)$ was employed to investigate the influence of $\mathrm{pH}$ on the speciation of aluminium. Filtered $(0.1 \mu \mathrm{m})$ synthetic samples [26] in the $\mathrm{pH}$ range from 3.0 to 8.0 were analysed. The results are presented in figure 1 . It is evident that the distribution of aluminium species varies significantly from the acidic to alkaline $\mathrm{pH}$ region. The increasing ionic strength of the eluent during the chromatographic run (gradient elution) enabled separation of positively charged aluminium species. The charge of the separated aluminium species was presumed on the basis of the retention times, while the identification of a particular aluminium species was based on theoretical predictions [29]. $\mathrm{Al}^{3+}$ is eluted between 4.0 and $5.5 \mathrm{~min}$ with a

Table I. Measurement parameters for determination of aluminium by ETAAS with Zeeman background correction.

\begin{tabular}{|c|c|c|c|c|c|c|}
\hline $\begin{array}{l}\text { Wavelength } \\
\text { Spectral bandwidth } \\
\text { Lamp current } \\
\text { Sample volume }\end{array}$ & & & & & & \\
\hline \multirow[t]{2}{*}{ Stage No. } & \multirow[t]{2}{*}{ Stage } & \multicolumn{2}{|c|}{ Temp. $\left({ }^{\circ} \mathrm{C}\right)$} & \multicolumn{2}{|c|}{ Time $(s)$} & \multirow{2}{*}{$\begin{array}{c}\text { Gas Flow } \\
\left(\mathrm{cm}^{3} \mathrm{~min}^{-1}\right)\end{array}$} \\
\hline & & Start & End & Ramp & Hold & \\
\hline 1 & Dry & 60 & 90 & 15 & 5 & 200 \\
\hline 2 & Dry & 90 & 100 & 10 & 10 & 200 \\
\hline 3 & Dry & 100 & 150 & 20 & 10 & 200 \\
\hline 4 & Ash & 150 & 1000 & 20 & 20 & 100 \\
\hline 5 & Atom & 2700 & 2700 & 0 & 4 & 0 \\
\hline 6 & Clean & 2800 & 2800 & 0 & 4 & 200 \\
\hline 7 & Cool & I & I & 0 & 5 & 200 \\
\hline
\end{tabular}




\section{Original articles}
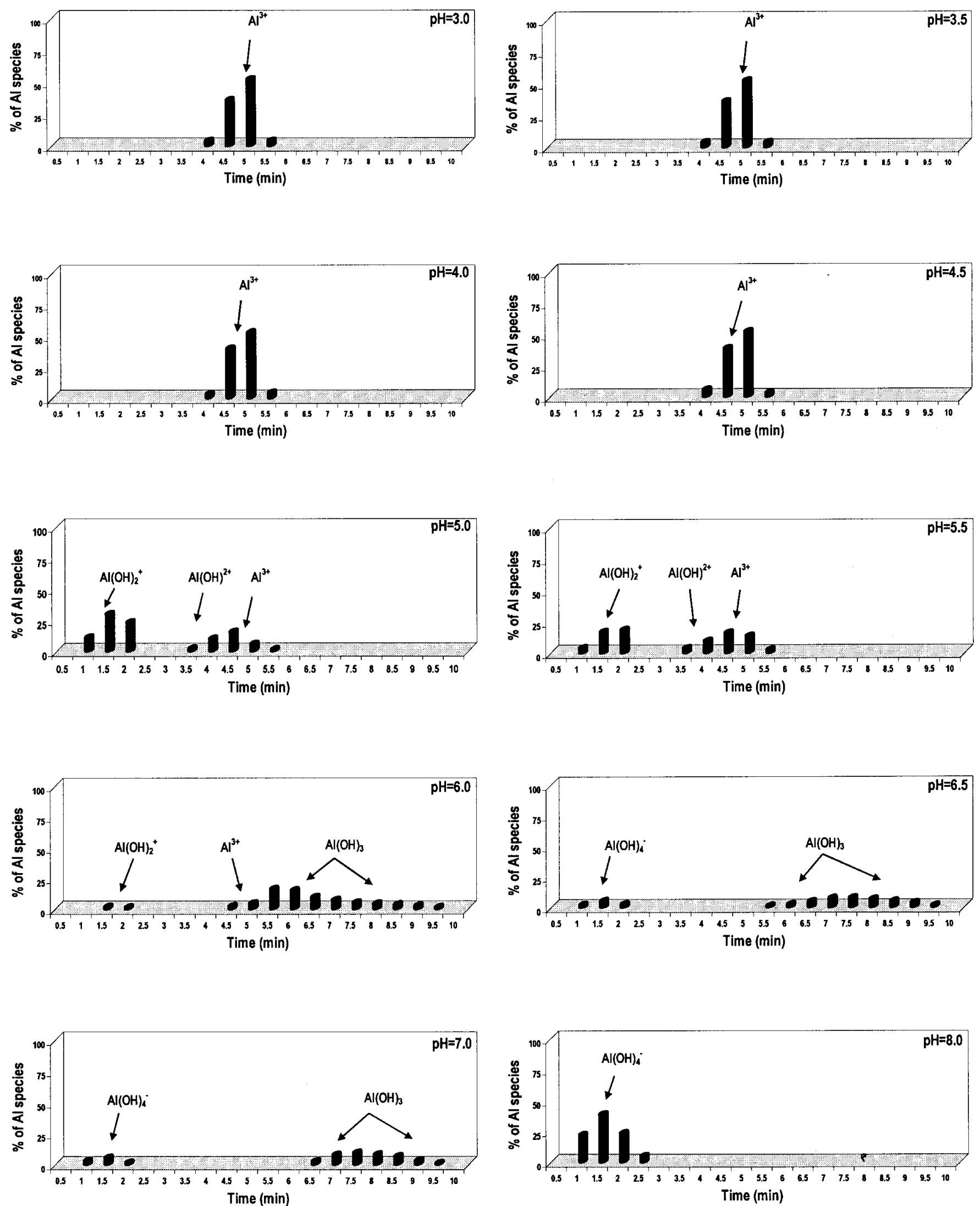

Fig. 1. Influence of $\mathrm{pH}$ on the distribution of aluminium species $\left(250 \mathrm{ng} \mathrm{cm}^{-3} \mathrm{Al}\right)$ employing FPLC with ETAAS detection (fraction collection $\left.0.5 \mathrm{~cm}^{3}\right)$. The percentage of monomeric aluminium species of filtered $(0.1 \mu \mathrm{m})$ synthetic samples was determined using a Mono $\mathrm{S}$ HR 5/5 column, a sample volume of $1 \mathrm{~cm}^{3}$, water- $\left.\mathrm{NH}_{4} \mathrm{NO}_{3}(8 \mathrm{~mol} \mathrm{dm})^{-3}\right)$ linear gradient elution in 10 min, and at flow rate of $1 \mathrm{~cm}^{3} \min ^{-1}, n=2$. 
peak maximum at $5.0 \mathrm{~min} . \mathrm{Al}(\mathrm{OH})^{2+}$ elutes between 3.5 and $4.5 \mathrm{~min}$ with a peak maximum at $4.5 \mathrm{~min}$. Although the retention times for $\mathrm{Al}^{3+}$ and $\mathrm{Al}(\mathrm{OH})^{2+}$ are close together it is still possible to distinguish between these two species. $\mathrm{Al}(\mathrm{OH})_{2}^{+}$is eluted with the solvent front (retention time $1.5 \mathrm{~min})$ and is completely separated from $\mathrm{Al}^{3+}$ and $\mathrm{Al}(\mathrm{OH})^{2+}$. $\mathrm{Al}(\mathrm{OH})_{3}$ is eluted as a broad peak from 5.5 to $9.5 \mathrm{~min}$ and does not interfere with the separation of positively charged monomeric aluminium species. Spectrophotometry [6-13], chelating ion-exchange chromatography [14-17], ion-chromatography [18-21] and high performance liquid chromatography [22-25] are able to determine only the sum of labile monomeric aluminium species. The advantage of the present FPLC - ETAAS procedure lies in its ability to distinguish between $\mathrm{Al}^{3+}, \mathrm{Al}(\mathrm{OH})^{2+}$ and $\mathrm{Al}(\mathrm{OH})_{2}^{+}$monomeric aluminium species at low concentration levels, which is of great importance in toxicological investigations. From the data of figure 1 it is also evident that at $\mathrm{pH}<4.5 \mathrm{Al}^{3+}$ is the predominant species. At $\mathrm{pH} 5.0-5.5 \mathrm{Al}^{3+}, \mathrm{Al}(\mathrm{OH})^{2+}$ and $\mathrm{Al}(\mathrm{OH})_{2}^{+}$are present. At a pH of $6.0 \mathrm{Al}(\mathrm{OH})_{3}$ appears and is the predominant species up to $\mathrm{pH}$ of 7.0. At a $\mathrm{pH}$ 's higher than 6.5 there are no positively charged monomeric aluminium species. $\mathrm{Al}(\mathrm{OH})_{4}^{-}$, which is eluted with a solvent front appears in small quantities at $\mathrm{pH}$ of 6.5 and becomes the prevailing aluminium species at $\mathrm{pH}$ of 8.0. These data are in agreement with the reported distribution of soluble aluminium monomeric species in aqueous solutions calculated on the basis of thermodynamic equilibrium constants [29]. Polymeric aluminium species do not interfere with the determination of monomeric species and were strongly adsorbed on the resin column.

\section{Linearity and repeatability of measurements}

The repeatability of measurement tested for six parallel determinations $\left(250 \mathrm{ng} \mathrm{cm}^{-3} \mathrm{Al}, \mathrm{pH} 4.0\right)$ by the FPLC ETAAS procedure was found to be $\pm 5.0 \%$ for separated aluminium species. At a lower concentration level from 10.0 to $25.0 \mathrm{ng} \mathrm{cm} \mathrm{cm}^{-3} \mathrm{Al}$ the repeatability of measurement was $\pm 10.0 \%$. Linearity of measurement was obtained up to $500 \mathrm{ng} \mathrm{cm}^{-3}$ of total aluminium species. When $1 \mathrm{~cm}^{3}$ of sample was injected on the column resin, the limit of detection (LOD) calculated on a $3 \mathrm{~s}$ basis for particular aluminium species was $3.0 \mathrm{ng} \mathrm{cm}^{-3}$.

\section{Influence of inorganic and organic complexing ligands on the distribution of aluminium species}

The influence of some inorganic and organic ligands, which are frequently present in the terrestrial environment, on the distribution of aluminium species by the FPLC - ETAAS procedure was investigated. Synthetic standard solutions of various aluminium compounds $\left(250 \mathrm{ng} \mathrm{cm}^{-3} \mathrm{Al}\right)$ were examined at $\mathrm{pH} 4.0$ and 6.0 since the majority of samples analyzed fit within this $\mathrm{pH}$ range. Samples were filtered $(0.1 \mu \mathrm{m})$ before analysis. The data are presented in figure 2 .

It is evident that Al-chloride and Al-sulphate exhibit the same behaviour as $\mathrm{Al}$-nitrate at $\mathrm{pH}$ 4.0. At $\mathrm{pH} 6.0, \mathrm{Al}(\mathrm{SO})_{4}^{+}$ together with $\mathrm{Al}(\mathrm{OH})_{2}^{+}$species are eluted with a solvent front and the remaining monomeric species $\left(\mathrm{Al}(\mathrm{OH})_{3}\right)$ as a broad peak from 6.0 to $9.5 \mathrm{~min}$.

Al-fluoride exhibits different behaviour from Al-nitrate at both pH's. On the basis of the retention times the charge of separated species was assumed, while the identification of
Al-fluoro complexes based on the theoretical data [29]. It can be noticed that $\mathrm{AlF}_{2}^{+}$is eluted at the retention time characteristic of $\mathrm{Al}(\mathrm{OH})_{2}^{+}$, and $\mathrm{AlF}^{2+}$ at the retention time for $\mathrm{Al}(\mathrm{OH})^{2+}$. At $\mathrm{pH} 4.0 \mathrm{AlF}_{2}^{+}$and $\mathrm{AlF}^{2+}$ are present, while at $\mathrm{pH} 6.0$ aluminium-fluoride exists only in small portion as $\mathrm{AlF}^{2+}$ species which is in equilibrium with $\mathrm{Al}(\mathrm{OH})_{3}$. These data match the reported theoretical predictions [29].

Al-oxalate exists predominantly as a negatively charged complex $\mathrm{Al}(\mathrm{ox})_{2}^{-}$, and at lower $\mathrm{pH}$ 's also as a positively charged $\mathrm{Al}(\mathrm{ox})^{+}$complex and aqua- $\mathrm{Al}^{3+}$ species [30]. $\mathrm{Al}(\mathrm{Ox})_{2}^{-}$and $\mathrm{Al}(\mathrm{Ox})^{+}$species are eluted with the solvent front. At $\mathrm{pH} 4.0$ the existence of $\mathrm{Al}(\mathrm{ox})_{2}^{-}, \mathrm{Al}(\mathrm{ox})^{+}$and $\mathrm{Al}^{3+}$ is evident, while at $\mathrm{pH} 6.0 \mathrm{Al}(\mathrm{ox})_{2}^{-}$and $\mathrm{Al}(\mathrm{OH})_{3}$ are present.

On the basis of the theoretical data [29] the prevailing Alcitrate species in the $\mathrm{pH}$ range from 5.0 to 8.0 are negatively charged $\mathrm{Al}(\mathrm{cit})^{x-}$ complexes. At $\mathrm{pH}$ from 3.0 to 4.5 neutral $\mathrm{Al}(\mathrm{cit})^{\circ}, \mathrm{Al}(\mathrm{cit})^{x-}$ and $\mathrm{Al}^{3+}$ are the predominant species [29]. The experiments presented in figure 2 confirmed the existence of $\mathrm{Al}(\mathrm{cit})^{\circ}, \mathrm{Al}(\mathrm{cit})^{x-}$ and $\mathrm{Al}^{3+}$ at $\mathrm{pH} 4.0$, while at $\mathrm{pH}$ 6.0 $\mathrm{Al}(\mathrm{cit})^{x-}$ is quantitatively eluted with the solvent front.

Humic acid in the neutral $\mathrm{pH}$ range forms negatively charged complex species which are not stable at lower pH's [31]. It is evident from the data of figure 2 that at $\mathrm{pH} 4.0$ a small proportion of free $\mathrm{Al}^{3+}$ species is present. It is also evident that another chromatographic peak is eluted from 6.5 to $8.0 \mathrm{~min}$. With the present technique it was not possible to identify this positively charged aluminium species. At pH 6.0 negatively charged Al-humate complexes are quantitatively eluted with the solvent front.

\section{Determination of aluminium species in soil extracts and natural waters}

In order to evaluate the capability of the method for the speciation of aluminium in soil extracts and natural waters, various types of soil samples from an area which is not influenced by acid rain were analyzed. Natural waters from a polluted area close to a coalburning thermal power plant and from a non-polluted area were also selected and analyzed for total water-soluble aluminium and its species. The results of these measurements are summarized in tables II and III. A comparison of data for total water-soluble aluminium and its species determined by FPLC - ETAAS in soil extracts (Tab. II) indicates that 30 to $85 \%$ of aluminium exists as monomeric kinetically reactive species. The $\mathrm{pH}$ of acid soil extracts (4.7 and 4.9) was lower than the $\mathrm{pH}$ of clay and sand soils (6.0 and 6.5). It is further evident that aluminium species determined by FPLC - ETAAS are eluted with the solvent front which excludes the existence of free $\mathrm{Al}^{3+}$ and $\mathrm{Al}(\mathrm{OH})^{2+}$ species. On the basis of our investigation on influences of inorganic and organic ligands on the speciation of aluminium and taking into consideration the low organic matter content (below 5\%) of the samples analyzed, it can be concluded that the eluted aluminium species from acid soil extracts exist mostly in the form of $\mathrm{Al}(\mathrm{OH})_{2}^{+}$species. In sand and clay soil extracts $\mathrm{Al}(\mathrm{OH})_{2}^{+}$and $\mathrm{Al}\left(\mathrm{SO}_{4}\right)^{+}$species prevail.

Analyses of natural water samples are presented in table III. The $\mathrm{pH}$ of samples ranged from 4.1 to 7.6. Comparison of data for total water-soluble aluminium and its species determined by FPLC - ETAAS in soil extracts showed that up to $90 \%$ of aluminium exists as monomeric kinetically reactive species. Lysimetric waters (samples 1-9) 


\section{Original articles}

\section{$\mathrm{pH}=\mathbf{4 . 0}$}

\section{Al-chloride}
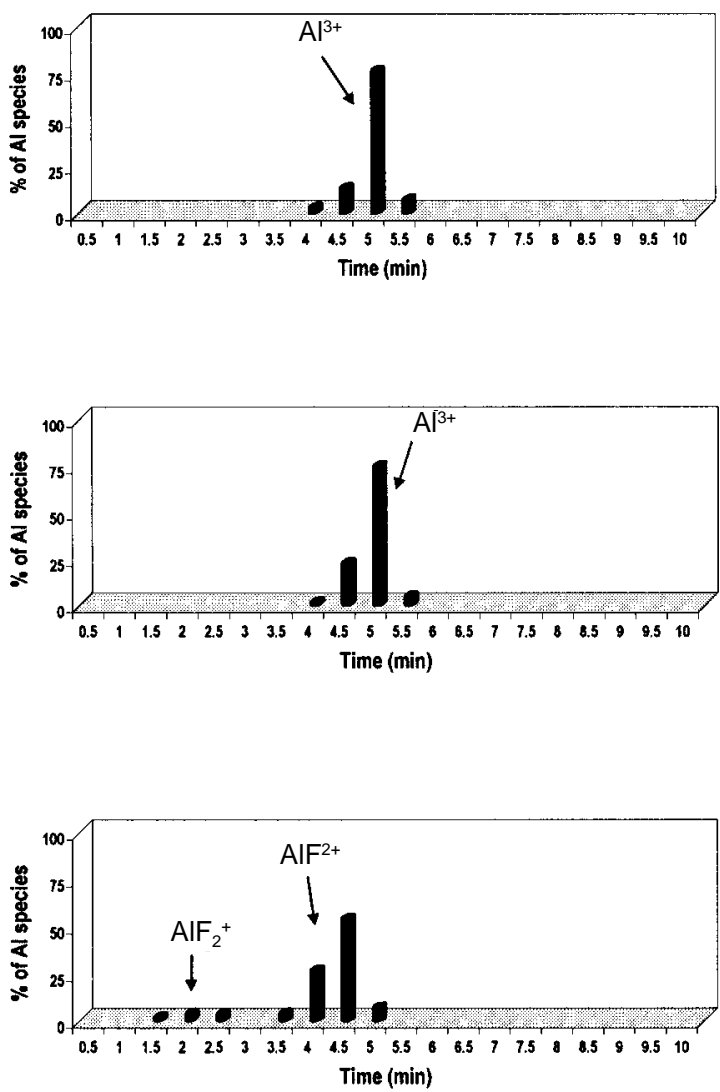

Al-oxalate
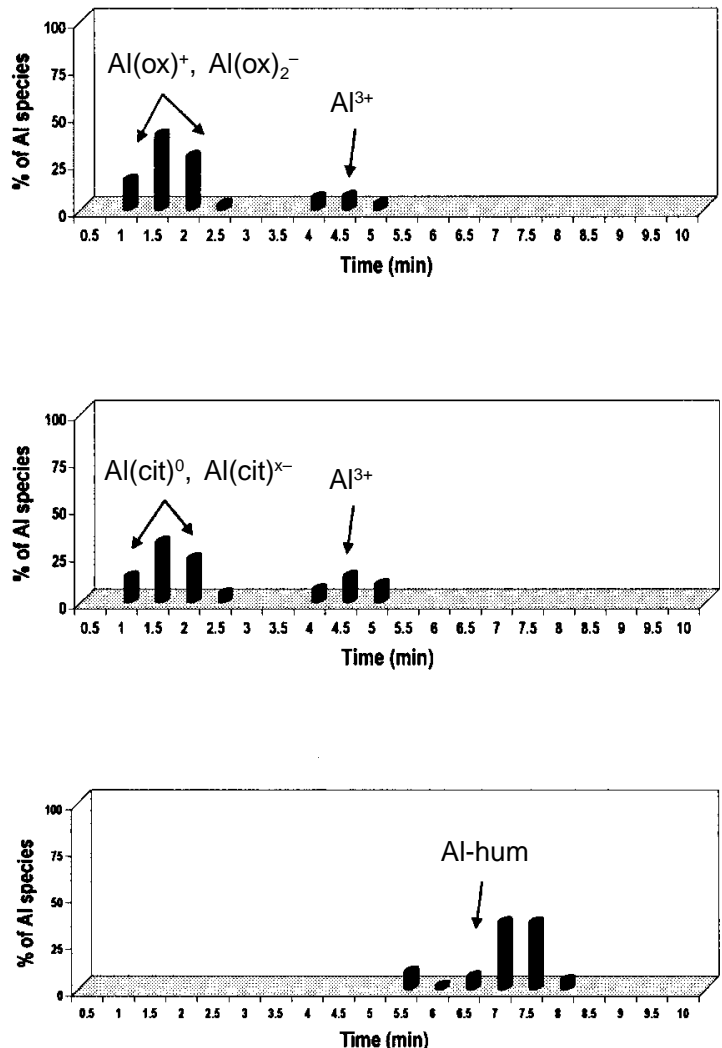

\section{$\mathrm{pH}=6.0$}
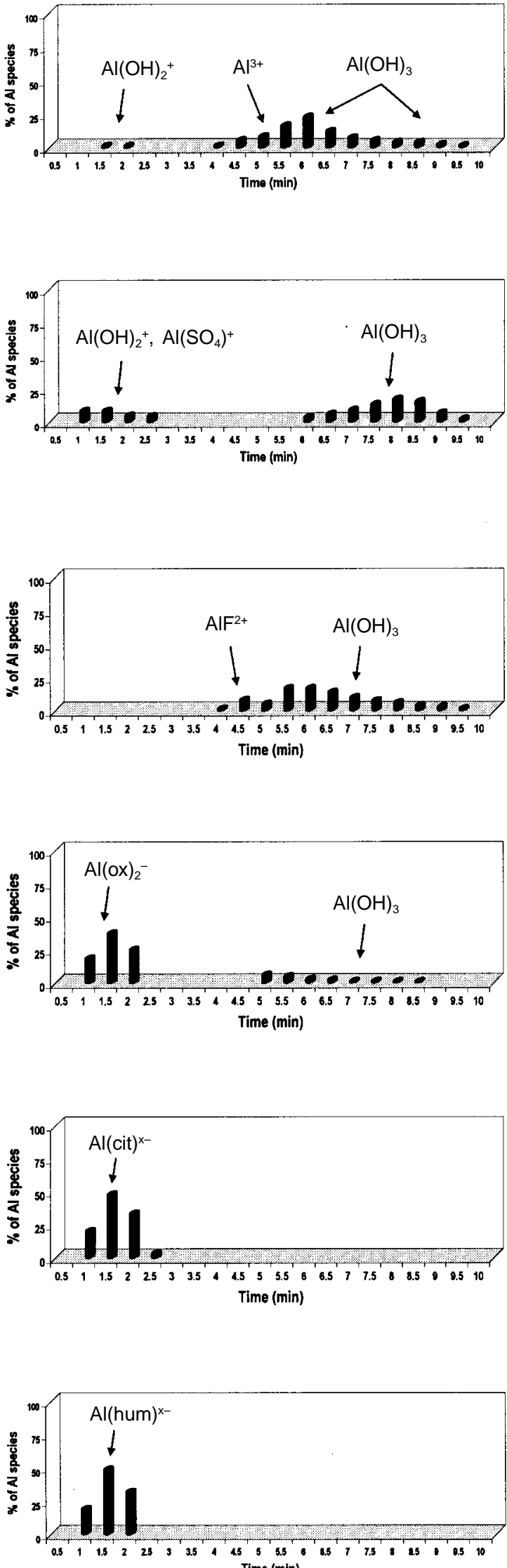

Fig. 2. Influence of some inorganic and organic ligands on the distribution of aluminium species $\left(250 \mathrm{ng} \mathrm{cm}{ }^{-3} \mathrm{Al}\right)$ at $\mathrm{pH} 4.0$ and 6.0 employing FPLC with ETAAS detection (fraction collection $0.5 \mathrm{~cm}^{3}$ ). The percentage of monomeric aluminium species of filtered $(0.1 \mu \mathrm{m})$ synthetic samples was determined using a Mono S HR 5/5 column, a sample volume of $1 \mathrm{~cm}^{3}, w^{2}$ ater- $\mathrm{NH}_{4} \mathrm{NO}_{3}\left(8 \mathrm{~mol} \mathrm{dm}^{-3}\right)$ linear gradient elution in $10 \mathrm{~min}$, and at flow rate of $1 \mathrm{~cm}^{3} \mathrm{~min}^{-1}, n=2$. 
Table II. Determination of total water-soluble aluminium and its species in filtered $(0.1 \mu \mathrm{m})$ soil extracts by cation-exchange FPLCETAAS, $n=2$.

\begin{tabular}{|c|c|c|c|c|c|c|c|}
\hline \multirow{2}{*}{$\begin{array}{l}\text { Sample } \\
\text { No. }\end{array}$} & \multirow{2}{*}{$\begin{array}{c}\text { Sample } \\
\text { characteristic }\end{array}$} & \multirow{2}{*}{$\begin{array}{l}\text { Total water soluble } \\
\qquad \mathrm{Al}\left(\mathrm{ng} \mathrm{\textrm {cm } ^ { - 3 } )}\right.\end{array}$} & \multirow{2}{*}{$\begin{array}{c}\text { pH of soil } \\
\text { extract }\end{array}$} & \multicolumn{4}{|c|}{ FPLC -ETAAS $\left(\mathrm{ng} \mathrm{cm}^{-3}\right)$} \\
\hline & & & & $t_{R}=1.5 \mathrm{~min}$ & $t_{R}=4.5 \mathrm{~min}$ & $t_{R}=5.0 \mathrm{~min}$ & $t_{R}=6.5-8 \mathrm{~min}$ \\
\hline 1 & Sand soil & 47.1 & 6.5 & 41.4 & $*$ & $*$ & $*$ \\
\hline 2 & Acid soil (Lipovci) & 164 & 4.9 & 120 & $*$ & $*$ & $*$ \\
\hline 3 & Clay soil & 640 & 6.0 & 436 & $*$ & $*$ & $*$ \\
\hline 4 & Acid soil (Filovci) & 70.0 & 4.7 & 21.9 & $*$ & $*$ & $*$ \\
\hline
\end{tabular}

$*<$ LOD.

Table III. Determination of total aluminium and its species in filtered $(0.1 \mu \mathrm{m})$ natural water samples by cation-exchange FPLC-ETAAS, $n=2$.

\begin{tabular}{|c|c|c|c|c|c|c|c|}
\hline \multirow{2}{*}{$\begin{array}{l}\text { Sample } \\
\text { No. }\end{array}$} & \multirow{2}{*}{$\begin{array}{c}\text { Sample } \\
\text { characteristic }\end{array}$} & \multirow{2}{*}{$\begin{array}{l}\text { Total Al } \\
\left(\mathrm{ng} \mathrm{cm}^{-3}\right)\end{array}$} & \multirow{2}{*}{$\begin{array}{c}p H \\
\text { sample }\end{array}$} & \multicolumn{4}{|c|}{ FPLC - ETAAS $\left(\mathrm{ng} \mathrm{cm}^{-3}\right)$} \\
\hline & & & & $t_{R}=1.5 \mathrm{~min}$ & $t_{R}=4.5 \mathrm{~min}$ & $t_{R}=5.0 \mathrm{~min}$ & $t_{R}=6.5-8 \mathrm{~min}$ \\
\hline 1 & $\begin{array}{l}\text { Lysimetric water } \\
\text { (under } O_{\mathrm{h}} \text { horizon, } \\
\text { spruce stand) } \mathbf{P}\end{array}$ & $2030^{\text {ICP }}$ & 4.4 & 280 & $*$ & 200 & 1320 \\
\hline 2 & $\begin{array}{l}\text { Lysimetric water } \\
\left(50 \mathrm{~cm} \text { under } O_{\mathrm{h}} \text { horizon, }\right. \\
\text { spruce stand })^{\mathrm{P}}\end{array}$ & 27.2 & 5.0 & 13.2 & $*$ & * & 12.8 \\
\hline 3 & $\begin{array}{l}\text { Lysimetric water (under } \\
O_{\mathrm{h}} \text { horizon, beech stand) }\end{array}$ & $740^{\text {ICP }}$ & 4.6 & 150 & $*$ & 260 & 240 \\
\hline 4 & $\begin{array}{l}\text { Lysimetric water } \\
\left(50 \mathrm{~cm} \text { under } O_{\mathrm{h}} \text { horizon, }\right. \\
\text { beech stand })^{\mathbf{P}}\end{array}$ & 26.5 & 5.2 & 1.2 & $*$ & 2.2 & 20.7 \\
\hline 5 & $\begin{array}{l}\text { Lysimetric water } \\
\text { (under } O_{\mathrm{h}} \text { horizon, } \\
\text { spruce stand) }\end{array}$ & 184 & 4.6 & 80.3 & 3.8 & 28.4 & 52.0 \\
\hline 6 & $\begin{array}{l}\text { Lysimetric water }(50 \mathrm{~cm} \\
\text { under } O_{\mathrm{h}} \text { horizon, } \\
\text { spruce stand })^{\mathbf{N P}}\end{array}$ & 30.2 & 5.3 & 13.2 & $*$ & 4.1 & 14.3 \\
\hline 7 & $\begin{array}{l}\text { Lysimetric water } \\
\text { (under } O_{\mathrm{h}} \text { horizon, } \\
\text { clearing) }\end{array}$ & 449 & 4.7 & 176 & $*$ & 52.7 & 198 \\
\hline 8 & 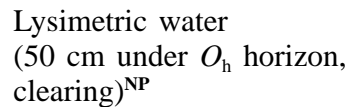 & 214 & 5.0 & 33.7 & 8.9 & 85.0 & 64.0 \\
\hline 9 & $\begin{array}{l}\text { Lysimetric water } \\
\text { (under } O_{\mathrm{h}} \text { horizon, } \\
\text { beech stand) }\end{array}$ & 470 & 5.6 & 226 & 7.7 & 82.6 & 139 \\
\hline 10 & Tap water & 5.2 & 7.6 & 4.7 & $*$ & $*$ & $*$ \\
\hline 11 & Surface water & 4.6 & 7.6 & 4.4 & $*$ & $*$ & * \\
\hline
\end{tabular}

ICP determined by ICP-AES,

$\mathbf{P}$ polluted area,

NP non-polluted area

* <LOD.

from forest soils of polluted and non-polluted area are rich in fulvic and humic substances. The $\mathrm{pH}$ of the analyzed waters ranged from 4.4 to 5.6 and in the upper soil horizon (under organic horizon $O_{\mathrm{h}}$ ) in general by 0.5 unit lower than in the lower soil horizon ( $50 \mathrm{~cm}$ below organic horizon $O_{\mathrm{h}}$ ). The typical distribution of aluminium species at these $\mathrm{pH}$ 's (compare data with those from Figs. 1 and 2) indicates that aluminium is bound predominantly to humate species (retention times 1.5 and $6.5-8.0 \mathrm{~min}$ ) and also exists partially as $\mathrm{Al}^{3+}, \mathrm{Al}(\mathrm{OH})^{2+}$ and $\mathrm{Al}(\mathrm{OH})_{2}^{+}$species. Tap and surface waters (samples 10 and 11) have higher pH's (7.6) than lysimetic waters. Species which are eluted with the solvent front at this $\mathrm{pH}$ indicate the presence of negatively charged monomeric aluminium species (compare data from Figs. 1 and 2). Therefore, monomeric aluminium species in tap water correspond to $\mathrm{Al}(\mathrm{OH})_{4}^{-}$, while in surface water they represent the sum of $\mathrm{Al}(\mathrm{OH})_{4}^{-}$and aluminium bound to humate. 


\section{Original articles}

When $1 \mathrm{~cm}^{3}$ of sample was injected on the column resin, the limit of detection (LOD) calculated on a $3 \mathrm{~s}$ basis for particular aluminium species in soil extracts and natural water samples was found to be $3.0 \mathrm{ng} \mathrm{cm}^{-3}$.

\section{Conclusions}

A method was developed for speciation of monomeric aluminium species at $\mathrm{ng} \mathrm{cm}^{-3}$ concentration level. Aqueous $8 \mathrm{~mol} \mathrm{dm}^{-3} \mathrm{NH}_{4} \mathrm{NO}_{3}$ linear gradient elution was applied in the separation procedure, which was carried out on a Mono Q HR 5/5 strong cation-exchange column. Separated aluminium species were determined "off line" by ETAAS. The main advantage of $\mathrm{NH}_{4} \mathrm{NO}_{3}$ as eluent was its ability to decompose quantitatively in the graphite tube during the ashing step. Under the recommended analytical procedure reproducible measurements of separated aluminium species were obtained. In synthetic aqueous solutions the separation and quantitative determination of $\mathrm{Al}^{3+}$ (retention time $5.0 \mathrm{~min}$ ), $\mathrm{Al}(\mathrm{OH})^{2+}$ (retention time $4.5 \mathrm{~min}$ ) and $\mathrm{Al}(\mathrm{OH})_{2}^{+}$ (retention time $1.5 \mathrm{~min}$ ) was possible. In the presence of inorganic and organic complexing ligands some other aluminium complexes also coelute with $\mathrm{Al}(\mathrm{OH})_{2}^{+}$and $\mathrm{Al}(\mathrm{OH})^{2+}$ species. The analytical procedure developed was successfully employed in speciation of aluminium in soil extracts

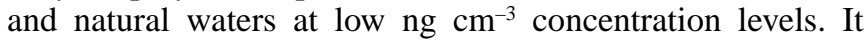
was found experimentally that monomeric aluminium in acid soil extracts exists mostly in the form of $\mathrm{Al}(\mathrm{OH})_{2}^{+}$species, while in sand and clay soil extracts it is predominantly present as $\mathrm{Al}(\mathrm{OH})_{2}^{+}$and $\mathrm{Al}\left(\mathrm{SO}_{4}\right)^{+}$species. In lysimetric waters from forest soils of polluted and non-polluted areas rich in fulvic and humic substances monomeric aluminium was bound mostly in humate complexes. In tap water the prevailing monomeric aluminium species was found to be $\mathrm{Al}(\mathrm{OH})_{4}^{-}$, while in surface water monomeric aluminium species represented the sum of $\mathrm{Al}(\mathrm{OH})_{4}^{-}$and aluminium bound to humate.

\section{Acknowledgements}

The financial support of the Ministry of Science and Technology of Slovenia is gratefully acknowledged. The authors would like to thank Matej Rupelj of the Forestry Institute of Slovenia for providing lysimetric water samples.

\section{References}

1. Miller, E. K.; Huntington, T. G.; Johnson, A. H.; Friedland, A. J. J. Environ. Qual. 1992, 21, 345-352.

2. Kuo, S.; Brauen, S. E.; Jellum, E. J. Soil Sci. 1992, 153, 365372.
3. Neville, C. M.; Campbell, P. G. C. Water Air Soil Pollut. 1988, 42, 311-327.

4. Freda, J. Environ. Pollut. 1991, 71, 305-328.

5. Delhaize, E.; Ryan, P. R. Plant Physiol. 1995, 107, 315-321.

6. Morrison, G. M. Analyst 1990, 115, 1371-1373.

7. Achilli, A.; Ciceri, G.; Ferraroli, R.; Culivicchi, G.; Pieri, S. Water Air Soil Pollut. 1991, 57-58, 139-148.

8. Luster, J.; Yang, A.; Sposito, G. Soil Sci. Soc. Am. J. 1993, 57, 976-980.

9. Garcia Alonso, J. I.; Lopez Garcia, A.; Sanz-Medel, A.; Blanko Gonzales, E.; Ebdon, L.; Jones, P. Anal. Chim. Acta 1989, 225, 339-350.

10. Clarke, N.; Danielsson, L. G.; Sparen, A. Intern. J. Environ. Anal. Chem. 1992, 48, 77-100.

11. Fairman, B.; Sanz-Medel, A. Intern. J. Environ. Anal. Chem. 1993, 50, 161-171.

12. Fairman, B.; Sanz-Medel, A.; Gallego, M.; Jose Quintela, M.; Jones, P.; Benson, R. Anal. Chim. Acta. 1994, 286, 401-409.

13. Hawke, D. J.; Powell, H. K. J. Anal. Chim. Acta 1994, 299, 257-268.

14. Miller, J. R.; Andelman, J. B. Wat. Res. 1987, 8, 999-1005.

15. Courtijn, E.; Vandecasteele, C.; Dams, R Sci. Tot. Environ. 1990, 90, 191-202.

16. Kozuh, N.; Milacic, R.; Gorenc, B. Annali di Chimica 1996, $86,99-113$

17. Kozuh, N.; Milacic, R.; Gorenc, B.; Abollino, O.; Sarzanini, C. Intern. J. Environ. Anal. Chem. 1997, 67, 27-40.

18. Bertsch, P. M.; Anderson, M. V. Anal. Chem. 1989, 61, 535539.

19. Willett, I. R. Soil Sci. Soc. Am. J. 1989, 53, 1385-1391.

20. Gibson, J. A. E.; Willett, I. R. Commun. Soil Sci. Plant Anal. 1991, 22, 1303-1313.

21. Jones, P.; Paull, B. Anal. Proc. 1992, 29, 402-404.

22. Sutheimer, S. H.; Cabaniss, E. Anal. Chem. 1995, 67, 23422349.

23. Borrmann, G.; Seubert, A. Anal. Chim. Acta 1996, 332, $233-$ 239.

24. Tsunoda, K.; Yagasaki, T.; Aizawa, S.; Akaiwa, H.; Satake, K. Anal. Sci. 1997, 13, 757-764.

25. Michalas, F.; Glavac, V.; Parlar, H. Fresenius J. Anal. Chem. 1992, 343, 308-312.

26. Mitrovic, B.; Milacic, R.; Pihlar, B. Analyst 1996, 121, 627634.

27. Milacic, R. Kozuh, N.; Mitrovic, B. Microchim. Acta 1998, 129, 139-145.

28. Downard, A. J.; Powell, K. J.; Money, S. D. Anal. Chim. Acta 1997, 349, 111-120.

29. Martin, R. B. Clin. Chem. 1986, 32, 1797-1806.

30. Driscoll, C. T.; Schecher, W. D. Aluminum in the Environment. Metal Ions in Biological Systems, Volume 24, Aluminum and Its Role in Biology, Sigel, S.; Sigel, A. Eds., Marcel Dekker, Inc., New York, 1988; Chapter 2, pp 59-122.

31. Backes, C. A.; Tipping, E. Water Res. 1987, 21, 211-216. 